\title{
SOSIALISASI MANAJEMEN LAKTASI PADA MASA PANDEMI DI DESA PUCUNG KECAMATAN BALONGPANGGANG GRESIK
}

\author{
Nur Jannah ${ }^{1}$, Yurilla Endah Muliatie ${ }^{2}$ \\ ${ }^{1}$ Universitas Wijaya Putra Surabaya \\ ${ }^{2}$ Universitas Wijaya Putra Surabaya \\ hafamnana2015@gmail.com, yurillaendah@uwp.ac.id
}

\begin{abstract}
Abstrak
Pandemi Covid-19 ini mengakibatkan kendala bagi ibu-ibu menyusui dimana mereka tidak bisa melakukan kegiatan Posyandu dikarenakan pelayanan Posyandu ditiadakan selama masa pandemi. Dan karena minimnya informasi tentang Virus Covid-19 di desa yang terkadang terkendala sinyal, listrik padam dan physical distancing yang membuat tidak bisa mengakses informasi yang ada di Posyandu Kesehatan Desa. Kegiatan ini bertujuan membantu Koordinator Poskesdes dalam mensosialisasikan manajemen laktasi di masa Pandemi Covid 19 dimana banyak ibu menyusui di desa Pucung, Kecamatan Balongpanggang, Gresik belum memahami tata cara pemberian ASI bagi penderita Covid 19. Metode yang dilakukan adalah dengan cara sosialisasi atau memberikan penyuluhan kepada para ibu menyusui dengan dibantu Petugas Kesehatan Desa. Memberikan pamflet yang berisi prosedur pemberian ASI di masa pandemi dan pemberian ASI bagi ibu yang terdeteksi Covid 19 serta membuat grup online yang beranggotakan para ibu menyusui di Desa Pucung dengan aplikasi whatsapp. Hasil yang diharapkan dari kegiatan ini antara lain adalah meningkatkan pengetahuan para ibu menyusui mengenai pandemi pada umumnya dan prosedur menyusui jika terdekteksi positif Covid 19 khususnya. Dampaknya ada peningkatan pada kesehatan Ibu Menyusui dan Bayi di masa pandemi Covid -19 serta peningkatan kesadaran masyarakat akan perilaku hidup bersih dan sehat.
\end{abstract}

Kata Kunci : pandemi, covid-19, manajemen laktasi

\section{PENDAHULUAN}

Data SDKI menunjukkan bahwa pemberian ASI sudah sangat lazim di Indonesia yaitu sebesar lebih dari $94 \%$ anak yang lahir dalam dua tahun terakhir sebelum survei pada semua karakteristik latar belakang pernah mendapat ASI setiap saat. Sayangnya dari angka tersebut hanya $49 \%$ atau hampir separo anak yang disusui dalam satu jam setelah kelahiran, dan sekitar 66\% disusui dalam satu hari setelah kelahiran. Persentase anak yang disusui dalam satu jam dan dalam satu hari setelah kelahiran menurun menurut pendidikan ibu, walaupun polanya tidak seragam. Anak yang dilahirkan dari ibu yang pada saat kelahiran ditolong oleh tenaga kesehatan profesional, cenderung lebih sedikit disusui dalam satu jam atau satu hari setelah kelahiran dibanding anak yang pada saat kelahiran ditolong oleh penolong persalinan tradisional atau lainnya. Selain itu, didapatkan fakta bahwa sebesar $60 \%$ anak yang dilahirkan mendapat makanan pralaktasi selain ASI pada tiga hari pertama kehidupan. Makanan pralaktasi lebih banyak diterima anak yang tinggal di perkotaan, yang pada saat kelahiran ditolong tenaga kesehatan profesional, lahir di fasilitas kesehatan, ibunya berpendidikan tamat SMTA keatas (SDKI, 2013)

$$
\text { Pangan dan Kesehatan }
$$


Generasi yang sehat, kuat dan cerdas dilahirkan dari seorang Ibu yang kuat juga. Seorang Ibu mulai mengandung sampai melahirkan selalu menjaga gizinya agar bayi yang dilahirkan sempurna dan menjadi dambaan orang tua. Pada saat ini dimana Ibu Hamil dan Menyusui dihadapkan dengan situasi pandemi Covid-19 diharapkan juga harus berhatihati untuk menjaga daya tahan tubuh. Menurut situs Pusat Pengendalian dan Pencegahan penyakit dilansir dari Huffpost, virus Corona Covid-19 ini belum terdeteksi dalam ASI. Pihaknya juga belum mengetahui Ibu menyusui bisa menularkan virus Corona jenis baru ke anak-anak atau tidak, baik saat hamil ataupun menyusui oleh sebab itu diperlukan manajemen laktasi yang baik sehingga terhindar dari virus Covid-19. Hal ini dilakukan dengan cara promosi kesehatan untuk meningkatkan keberhasilan menyusui dengan mengajarkan bagaimana menyusui yang benar serta langkah-langkah menyusui sesuai dengan protokol menyusui di masa pandemi Covid19.

Untuk program pengabdian masyarakat ini tim pengabdi sudah melakukan observasi terhadap masyarakat di Desa Pucung dimana di sana banyak ditemukan Ibu Menyusui yang kurang informasi bagaimana cara laktasi agar terhindar dari Covid-19 pada saat pandemi ini berlangsung. Kegiatan sosialisasi bekerjasama dengan Petugas Pos Kesehatan Desa setempat yang diharapkan bisa membantu mengurangi beban Petugas Medis karena Petugas Medis yang ada di Desa Pucung juga terbatas.

Peran tim pengabdi dan mitra dapat dijelaskan sebagai berikut:

Pertama, tim pengabdi melakukan penggalian masalah yang dihadapi oleh mitra kemudian mencarikan solusi yang tepat atas permasalahan tersebut. Selanjutnya tim pengabdi menyusun proposal yang berisi perencanaan program. Setelah program disusun kemudian tim pengabdi melakukan koordinasi awal dengan Koordinator Poskesdes di Desa Pucung, Kecamatan Balongpanggang, Gresik kapan sebaiknya dilaksanakan kegiatan untuk memberikan sosialisasi/penyuluhan mengenai manajemen Laktasi. Dan yang terakhir adalah tim pengabdi membuat publikasi pada media online, publikasi ilmiah yang berupa prosiding/jurnal dan laporan akhir hasil kegiatan.

Kedua, peran mitra adalah mengkomunikasikan kepada tim pengabdi permasalahan apa saja yang dihadapinya dan pada saat pelaksanaan sosialisasi/ penyuluhan mengenai manajemen Laktasi di masa pandemi Covid-19 ini, mitra menyediakan sumber daya yang dibutuhkan untuk mendukung kegiatan tersebut.

Mitra pada program pemberdayaan masyarakat ini adalah ibu Kosiah sebagai Koordinator Posyandu Kesehatan Desa (Poskesdes) di Desa Pucung, Kecamatan Balongpanggang, Gresik.

Permasalahan yang dihadapi oleh Ibu Kosiah antara lain adalah: Satu, minimnya informasi tentang Laktasi dimasa Pandemi Covid-19, informasi tentang suspek dan kasus terkonfirmasi Covid-19 untuk Ibu Menyusui pada saat pandemi ini berlangsung. Dua, banyak ibu menyusui tidak bisa keluar rumah atau sekedar kontrol ke Poskedes karena adanya physical distancing dan pelayanan Poskesdes untuk sementara ditiadakan. Ketiga, Jumlah tenaga medis di Pos Kesehatan Desa sangat terbatas yang tidak memungkinkan bagi mereka untuk menjangkau satu persatu ibu menyusui di desa tersebut.

Solusi yang ditawarkan antara lain adalah: Pertama, memberikan penyuluhan/sosialisasi dengan bantuan Koordinator Posyandu Kesehatan Desa (Poskesdes) mengenai bagaimana melakukan laktasi dengan baik dan benar agar terhindar dari Covid-19. Kedua, memberikan informasi secara online kepada para ibu menyusui dengan membuat grup online pada aplikasi whatsapp. Ketiga, membuat pamflet ataupun gambar edukasi mengenai tata cara menyusui di saat pandemi Covid-19 serta tata cara menyusui bagi ibu yang terdeteksi Covid-19.

Adapun kegiatan pengabdian ini bertujuan untuk memberikan penyuluhan atau sosialisasi mengenai manajemen laktasi. Secara keseluruhan, luaran yang dihasilkan dari usulan kegiatan pengabdian ini bertujuan untuk membantu meningkatkan pemahaman tentang manajemen laktasi di masa pandemi Covid-19 serta hal-hal yang 
terkait dengan ibu menyusui yang terdeteksi Covid19.

Luaran dari kegiatan Program Pemberdayaan Masyarakat ini antara lain adalah: Pertama, dapat membantu program pemerintah untuk memberikan informasi akurat mengenai Covid-19 sampai ke pelosok desa khususnya bagi Ibu yang menjalankan Laktasi yang diharapkan ke depannya para Ibu menyusui ini faham dan dapat melakukan bagaimana cara Laktasi yang benar dan sehat. Kedua, dapat memberikan akses informasi secara online sehingga Ibu Menyusui yang ada di desa faham dan belajar tentang teknologi informasi kesehatan pada saat pandemi ini berlangsung. Ketiga, meringankan kerja tenaga Medis dengan membantu Edukasi Manajemen Laktasi pada Ibu-Ibu Menyusui yang ada di Desa Pucung, Kecamatan Balongpanggang, Gresik.

Melalui kegiatan program pemberdayaan masyarakat ini tim pengabdi berharap bisa ikut berperan serta aktif dalam mendukung program pemerintah dengan gerakan kesadaran pemberian ASI eksklusif bagi masyarakat untuk pemenuhan gizi dan perkembangan bayi secara maksimal karena mereka adalah aset masa depan bangsa Indonesia.

Kegiatan sosialisasi manajemen Laktasai telah dilaksanakan pada tanggal 15 Juli 2020 dan hasil laporan kegiatan pengabdian ini telah dipublikasikan pada media online Radar Surabaya pada tanggal 20 Juli 2020.

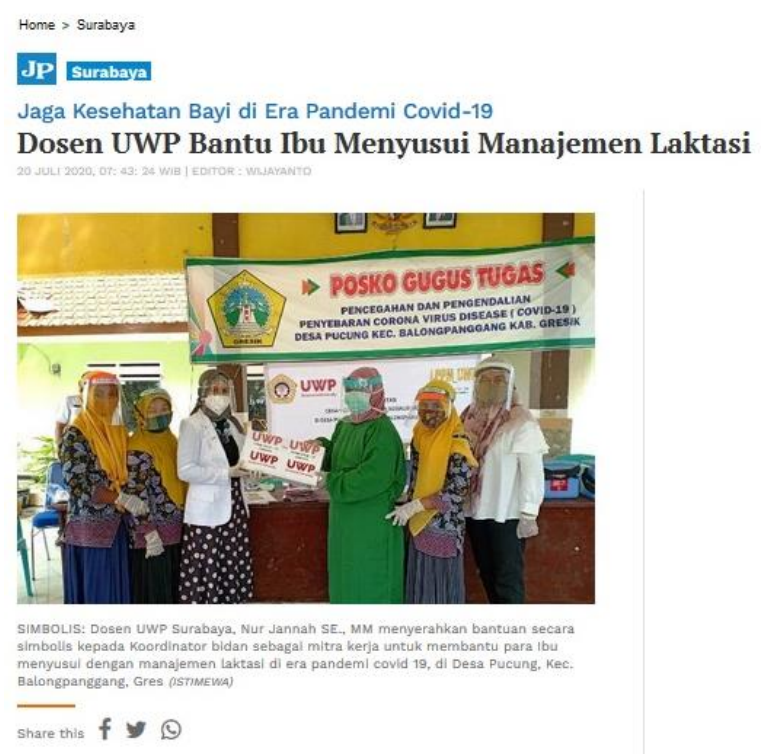

Gambar 1. Publikasi Media Online Radar Surabaya

\section{TINJAUAN PUSTAKA}

\section{Pengertian Menyusui atau Laktasi}

Menyusui atau laktasi adalah suatu proses dimana seorang bayi menerima air susu dari payudara ibu (Sumastri, 2012). Menyusui yang dikategorikan ASI eksklusif adalah gerakan menghisap dan menelan dari mulut sang bayi langsung ke puting susu ibu (Sitepoe, 2013). Pada bayi baru lahir akan menyusu lebih sering, rata-rata 10-12 kali menyusu tiap 24 jam. Bayi yang sehat dapat mengosongkan payudara sekitar 5-7 menit, sedangkan ASI dalam lambung bayi akan kosong dalam waktu 2 jam (Astutik, 2014).

Laktasi adalah bagian terpadu dari proses reproduksi yang memberikan makanan bayi secara ideal dan alamiah serta merupakan dasar biologi dan psikologi yang dibutuhkan untuk pertumbuhan. Air Susu Ibu (ASI) merupakan makanan yang ideal bagi pertumbuhan neonatus (Nugroho, 2011, p.3).

Komponen yang terkandung di dalam ASI sebagai sumber nutrisi untuk pertumbuhan dan perlindungan pertama terhadap infeksi. Proses 
pembentukan air susu merupakan suatu proses yang kompleks melibatkan hipotalamus, dan payudara yang telah dimulai saat fetus sampai pada paska persalinan. ASI yang dihasilkan memiliki komponen yang tidak sama, dengan terjadinya kehamilan pada wanita akan berdampak pada pertumbuhan payudara dan proses pembentukan air susu (Laktasi).

\section{Pengertian Manajemen Laktasi}

Manajemen laktasi adalah upaya untuk mendukung keberhasilan laktasi di mulai saat masa kehamilan, melahirkan, dan masa menyusui. (Hayatin, dkk., 2019).

Air Susu Ibu (ASI) eksklusif sangat penting diberikan kepada bayi dari umur 0-6 bulan. Untuk menunjang keberhasilan ASI eksklusif para ibu hendaknya memiliki pengetahuan mengenai manajemen laktasi.

Manajemen laktasi merupakan upaya yang dilakukan untuk membantu ibu mencapai keberhasilan ASI eksklusif. Keberhasilan ASI eksklusif terdiri dari tiga indikator yaitu, Inisiasi Menyusui Dini, memberikan hanya ASI selama 6 bulan dan berat badan bayi yang selalu bertambah setiap bulannya. (Hendrik dan Putri, 2016).

World Health Organization (WHO) merekomendasikan pemberian ASI sekurangkurangnya selama 6 bulan pertama sejak bayi dilahirkan, atau biasa disebut dengan pemberian ASI eksklusif yang artinya hanya minuman yang lain tanpa indikasi medis (Yuliarti, 2010). Alasan pemberian ASI hingga bayi berusia 6 bulan yakni, komposisi ASI yang cukup untuk pertumbuhan dan perkembangan bayi apabila diberikan secara tepat dan benar, serta saat bayi berusia lebih dari 6 bulan sistem pencernaannya mulai matur (sempurna) sehingga mencegah kemungkinan kuman atau bakteri masuk langsung ke peredaran darah (Rukiyah, dkk, 2011).

\section{METODE}

Metode pelaksanaan pada program pemberdayaan masyarakat ini dilakukan dengan cara sosialisasi atau memberikan penyuluhan kepada para ibu menyusui dengan dibantu petugas kesehatan desa. Membuat grup online yang beranggotakan para ibu menyusui di Desa Pucung dengan aplikasi whatsapp.

Kegiatan ini diawali dengan pendataan jumlah ibu menyusui yang dilakukan oleh Petugas POSKESDES. Terdapat 43 orang ibu menyusui di Desa Pucung, Kecamatan Balongpanggang, Gresik. Kegiatan sosialisai/penyuluhan dibagi menjadi 3 kelompok dan dilaksanakan dengan durasi 2 jam untuk setiap kelompoknya. Hal ini dilakukan untuk menerapkan physical distancing dan menghindari kerumunan mengingat tempat diadakannya kegiatan ini tidaklah besar. Protokol kesehatan juga dilaksanakan dengan ketat karena yang terlibat pada kegiatan ini adalah para ibu menyusui dan bayinya.

Selain dengan memberikan penyuluhan secara lisan mengenai bagaimana manajemen laktasi yang baik selama masa pandemi Covid 19, sosialisasi juga dilakukan dengan cara membagikan pamflet dan pembuatan grup laktasi pada media sosial whatsapp. Pamflet yang disebar berisi tentang manajemen Laktasi dimasa pandemi yang diharapkan kedepannya ibu-ibu tersebut lebih memahami bagaimana manajemen Laktasi yang baik dimasa pandemi agar terhindar dari Covid-19.

Adapun pamflet yang dibagikan kepada para ibu menyusui ada 2 macam. Pamflet pertama berisi keterangan lengkap tata cara menyusui di masa pandemi Covid-19 bagi bayi sehat yang lahir dari ibu dengan status suspek Covid-19 dimana bayi termasuk kriteria kontak erat resiko rendah. Pada kriteria ini tidak diperlukan pemeriksaan Swab SarsCov-2 kecuali ada gejala. Kemudian pada pamflet pertama ini juga dijelaskan mengenai tata cara menyusui bagi bayi yang terlahir dari ibu berstatus terkonfirmasi Covid-19 dimana bayi termasuk kriteria kontak erat resiko tinggi. Pada kriteria ini harus dilakukan pemeriksaan Swab Sars-Cov-2 pada hari -1 dan hari ke 14. Contoh pamflet seperti di bawah ini: 


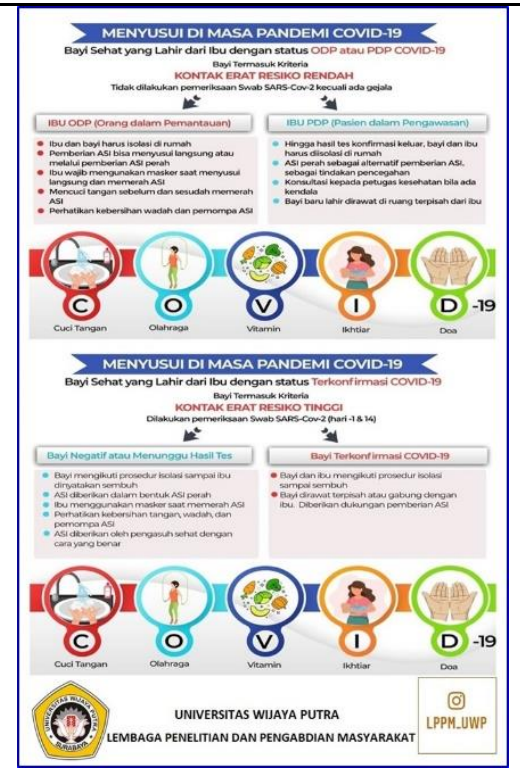

Gambar 2. Cara Menyusui di masa Pandemi Covid-19

Dan pamflet berikutnya berisi keterangan lengkap mengenai tata cara menyusui jika si ibu terdeteksi Covid-19. Disebutkan di dalam pamflet jika ibu menyusui tidak kuat untuk menyusui langsung maka bisa diberikan ASIP (ASI Perah). Ibu menyusui yang terkonfirmasi Covid harus mendapatkan dukungan penuh dari keluarga dan orang-orang disekitarnya. Karena pemberian ASI eksklusif dapat membantu tumbuh kembang bayi secara optimal maka opsi yang ditawarkan bisa melakukan rawat gabung antara ibu dan bayinya paska persalinan. Ibu menyusui yang terkonfirmasi Covid-19 dapat menyusui jika mereka menginginkannya yang tentunya harus dilakukan dengan protokol kesehatan seperti memakai masker pada saat menyusui, mencuci tangan dengan sabun sebelum dan sesudah memegang bayi dan yang terakhir adalah membersihkan dan mendesinfeksi permukaan benda yang sering disentuh ibu dan bayinya. Pada pamflet kedua ini juga diberikan cara menyimpan ASI perah pada lemari pendingin. Dengan pengaturan suhu pada lemari pendingin bisa ditentukan waktu yang diinginkan untuk penyimpanan ASI Perah. Adapun contoh pamflet seperti gambar di bawah ini:

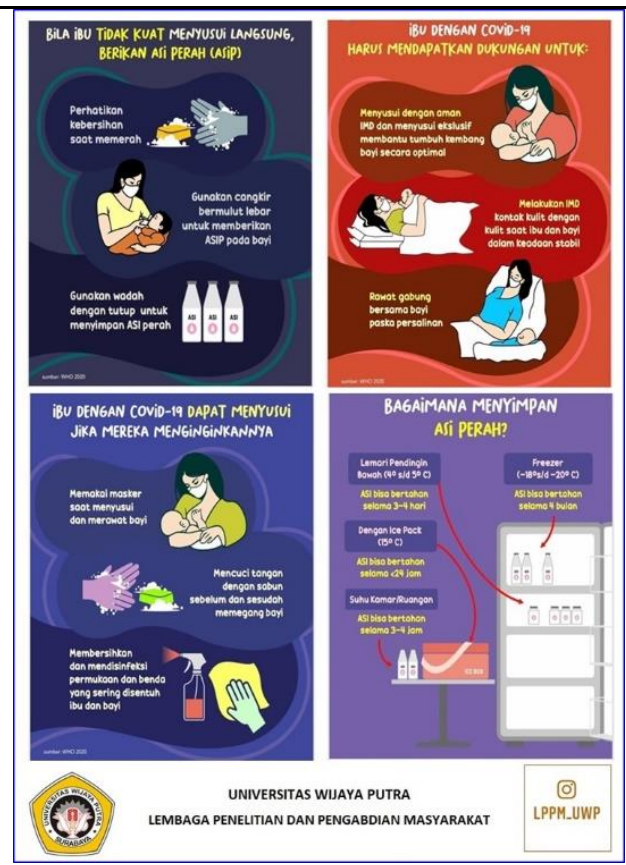

Gambar 3. Prosedur menyusui jika ibu terdeteksi Covid-19

Pada waktu yang telah disepakati antara tim pengabdi dengan koordinator Poskesdes Desa Pucung, Kecamatan Balongpanggang, Gresik dilaksanakan acara sosialisasi yang dimulai dengan pemeriksaan suhu tubuh dari para ibu menyusui peserta sosialisasi. Acara ini baru pertama kali diadakan kembali sesudah tiga bulan ditiadakan karena adanya pandemi. Para ibu menyusui tetap menerapkan protokol kesehatan dengan memakai masker dan balita yang dibawanya menggunakan face shield untuk menghindari hal yang tidak diinginkan.

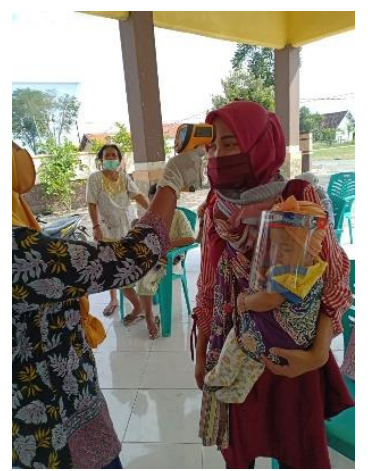

Gambar 4. Pemeriksaan Suhu Tubuh 
Kemudian kegiatan dimulai dengan pendaftaran peserta penyuluhan/sosialisasi sekaligus pembagian pamflet, masker, handsanitizer dan vitamin $\mathrm{C}$ kepada para ibu menyusui.

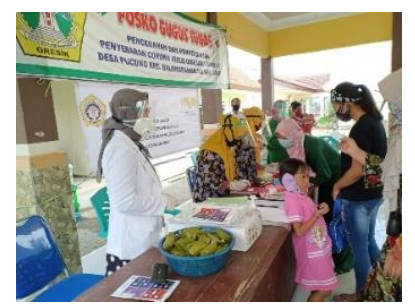

Gambar 5. Pendaftaran Peserta Sosialisasi

Selanjutnya adalah pemeriksaan kesehatan ibu dan bayinya dimana kegiatan seperti ini ditiadakan sejak adanya pandemi Covid-19 melanda Indonesia. Pemeriksaan ini meliputi pemeriksaan berat badan bayi apakah berat badannya sudah sesuai dengan umur bayi. Dan pemeriksaan kesehatan lainnya seperti ruam kulit, pertumbuhan gigi dan motorik bayi.

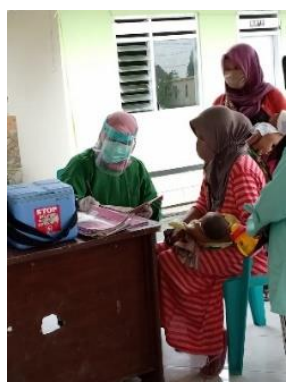

Gambar 6. Pemeriksaan kesehatan ibu dan bayinya

Sesudah para peserta sosialisasi/penyuluhan selesai melalui tahapan diatas maka dimulailah acara sosialisasi dengan menerapkan physical distancing diantara para peserta. Acara sosialisasi/penyuluhan ini terbagi menjadi 3 kelompok sehingga protokol kesehatan bisa diterapkan dengan efektif.

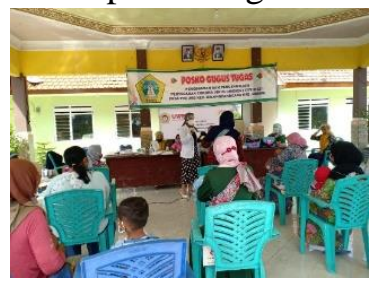

Gambar 7. Kegiatan Sosialisasi

Acara ini berjalan dengan lancar dan tampak antusiasme pada para ibu menyusui dan juga koordinator Poskesdes Desa Pucung, Kecamatan Balongpanggang, Gresik. Dimana para ibu menyusui bisa memeriksakan bayinya kembali di Poskesdes dan petugas Poskesdes juga bisa memberikan pelayanan kembali kepada para ibu menyusui di desa tersebut.

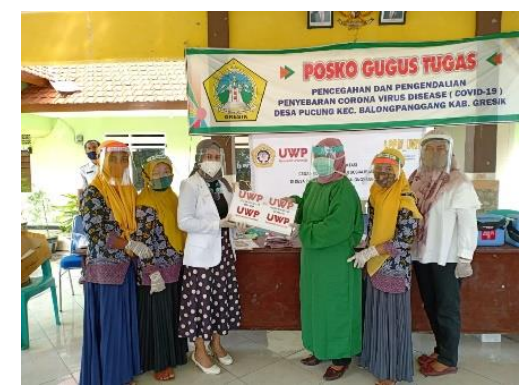

Gambar 8. Penutupan Kegiatan Sosialisasi dengan Protokol Kesehatan yang Ketat

Ucapan terima kasih yang sedalamdalamnya disampaikan oleh Ibu Kosiah sebagai koordinator Poskesdes Desa Pucung, Kecamatan Balongpanggang, Gresik kepada tim pengabdi karena sudah membantu meringankan pekerjaan mereka sebagai petugas Poskesdes dimana jumlah tenaga mereka sangat terbatas dibandingkan jumlah ibu menyusui yang ada di desa tersebut.

\section{HASIL DAN PEMBAHASAN}

Kegiatan ini merupakan perwujudan dari TriDharma Perguruan Tinggi yang salah satunya adalah pengabdian kepada masyarakat. Bermula dari keprihatinan dengan adanya pandemi Covid-19 yang tengah melanda berbagai belahan dunia yang membuat naluri tim pengabdi sebagai ibu dan dosen tersentuh untuk melakukan kegiatan yang dapat membantu masyarakat di sekitarnya. Memang kegiatan ini tidaklah besar ruang lingkupnya, tetapi paling tidak dengan adanya kegiatan ini 
menunjukkan kepedulian tim pengabdi terhadap masyarakat di sekitarnya.

Survei kegiatan telah dilakukan dari bulan AprilJuni 2020 dan beberapa pertemuan telah dilakukan sejak saat itu. Bekerjasama dengan Koordinator Bidan Desa dan para kadernya disepakati untuk diadakan sosialisasi di Era New Normal secara bertahap bersama dengan para kader untuk menyampaikan informasi mengenai manajemen laktasi pada saat pandemi Covid-19 kepada para ibu menyusui tentunya dengan protokol kesehatan yang sesuai. Kegiatan sosialisasi dilaksanakan pada tanggal 15 Juli 2020 bertempat di Poskesdes Desa Pucung, Kecamatan Balongpanggang Gresik. Dibantu oleh koordinator Poskesdes, sasaran kegiatan ini adalah para ibu menyusui yang kesulitan dalam mengakses informasi mengenai pandemi dan belum sepenuhnya memahami tata cara menyusui di masa pandemi. Materi yang diberikan ada 2 macam cara menyusui di masa pendemi Covid 19 dan prosedur menyusui jika ibu terdeteksi Covid 19.

Salah satu hal yang harus diperhatikan bila ibu menyusui positif Covid-19, maka sebaiknya ASI diberikan dengan ASI Perah (ASIP). Jadi ASI tersebut sebaiknya diperah oleh ibu dan diberikan kepada orang yang sehat. Selanjutnya orang yang sehat tersebut yang memberikan ASIP kepada bayi.

Tak hanya memberikan penyuluhan secara bertahap bersama dengan para kader dan para ibu menyusui di Desa Pucung, tim pengabdi juga memberikan bantuan yang berupa masker, Vitamin C, dan Handsanitizer.

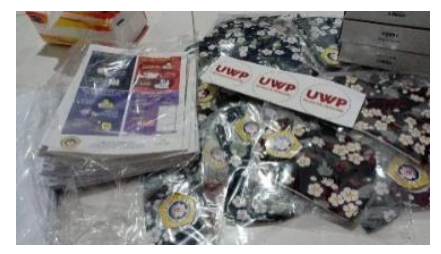

Gambar 9. Pamflet, Masker, Handsanitizer serta Vitamin C untuk Ibu-ibu Menyusui

Pemberian pamflet terkait manajemen laktasi dan seputar informasi Covid-19 ini sesuai dengan koordinasi yang telah dilakukan sebelumnya dan sesuai dengan arahan Koordinator Poskesdes untuk disosialisasikan kepada para ibu menyusui dimana hal ini diharapkan dapat meningkatkan pengetahuan para ibu menyusui mengenai pandemi pada umumnya dan prosedur menyusui jika terdeteksi positif Covid-19 khususnya.

Evaluasi dari kegiatan ini antara lain adalah: pertama, untuk evaluasi jangka pendek: dengan adanya sosialisasi/penyuluhan dibantu oleh koordinator Poskesdes (Posyandu Kesehatan Desa) untuk membagikan pamflet kepada Ibu-Ibu menyusui sehingga diharapkan mereka faham bagaimana melakukan laktasi dengan baik. Kedua, Menginformasikan dengan mendata para Ibu Menyusui untuk dimasukkan pada grup online pada aplikasi whatsapp, agar terpantau apabila ada Ibu Menyusui yang terdiagnosa Covid-19 pada saat pandemi ini berlangsung serta memberikan informasi bagaimana cara Laktasi disaat pandemi.

Sedangkan evaluasi jangka panjangnya adalah dengan membantu mereka membuatkan pamflet ataupun gambar edukasi tentang Covid-19 yang nantinya bisa disebar ke grup Online khusus Ibu Menyusui yang ada Di Desa Pucung, Kecamatan Balongpanggang, Gresik sehingga para Ibu Menyusui tidak ketinggalan informasi dalam pencegahan penularan Covid-19 ke depannya.

Dampak dan manfaat dari kegiatan ini antara lain adalah: pertama, dengan adanya kegiatan ini diharapkan ada peningkatan pada kesehatan Ibu Menyusui dan Bayi di masa pandemi Covid -19 yang harus benar benar dijaga dengan memahami manajemen Laktasi dan diharapkan bantuan masyarakat dalam hal ini keluarga untuk saling mengingatkan tentang kesehatan dan bahaya dari Virus Corona/Covid-19 ini. Kedua, memberikan informasi secara online dan pembagian pamflet sehingga dapat memudahkan informasi sosialisasi lewat koordinator Pos Kesehatan Desa. Ketiga, perbaikan tata nilai masyarakat dalam hal ini kesehatan karena masyarakat sudah mulai tumbuh kesadarannya untuk melaksanakan Perilaku Hidup Bersih dan Sehat (PHBS). Selalu memakai masker, 
sering mencuci tangan dengan sabun atau menggunakan handsanitizer dan menerapkan phisycal distancing jika berada diluar rumah.

Keberlanjutan kegiatan ini diharapkan timbulnya kesadaran para peserta dalam bentuk sikap dan tingkah laku untuk menjalankan manajemen laktasi sebagai upaya dalam kelancaran proses menyusui secara eksklusif.

\section{KESIMPULAN}

Kesimpulan dari kegiatan program pemberdayaan masyarakat ini antara lain adalah dapat membantu program pemerintah untuk memberikan informasi akurat mengenai Covid-19 sampai ke pelosok desa khususnya bagi Ibu yang menjalankan Laktasi dimana diharapkan kedepannya para Ibu menyusui ini faham dan dapat menjalankan bagaimana cara Laktasi yang benar dan sehat.

Dapat memberikan akses informasi secara online sehingga Ibu Menyusui yang ada di desa faham dan belajar tentang teknologi informasi kesehatan pada saat pandemi ini berlangsung.

Memperingan kerja tenaga Medis dengan membantu Edukasi Manajemen Laktasi pada Ibu-Ibu Menyusui yang ada di desa tersebut.

\section{SARAN}

\section{Bagi masyarakat.}

Diharapkan dengan adanya program pemberdayaan masyarakat yang dilaksanakan di Desa Pucung, Kecamatan Balongpanggang, Gresik ini ke depannya diharapkan dapat terjalin kerjasama yang berkelanjutan.

\section{Bagi Universitas.}

Untuk lebih aktif mendorong diadakannya pengabdian masyarakat yang dapat meningkatkan pengetahuan maupun taraf hidup masyarakat di sekitar kampus Univertsitas Wijaya Putra Surabaya.

\section{Bagi Tim Pengabdi.}

Lebih banyak lagi menggali potensi diri dan berpikir kreatif untuk mencari ide-ide yang bisa diterapkan para program pengabdian masyarakat dengan melakukan kegiatan yang lebih bermanfaat ke depannya.

\section{UCAPAN TERIMAKASIH}

Ucapan terimakasih disampaikan kepada Lembaga Penelitian dan Pengabdian Kepada Masyarakat Universitas Wijaya Putra Surabaya yang telah memberikan kontribusi dalam pelaksanaan kegiatan PKM ini dengan memberikan pendanaan internal dengan nomor 025.73/LPPM-UWP/K$\mathrm{I} / \mathrm{VI} / 2020$.

\section{REFERENSI}

Astutik, Reni Yuli. (2014). Payudara dan laktasi. Jakarta: Salemba Medika.

Depkes RI. (2014). Situasi dan analisis ASI eksklusif. Diakses 10 September 2020.

Enny Fitriahadi. (2020). Trik Menyusui Masa Pandemi Covid-19. Diakses 7 Maret 2020.

Hayatin, Nur, Alifatin, Aini, Andini, Thathit Manon, dan Kurniawati Dini. (2019). SIMOMI: aplikasi panduan laktasi dan konsultasi online berbasis mobile sebagai media pembelajaran mandiri tentang laktasi. Jurnal Perempuan dan Anak (JPA), 2 (2), 11-22. ISSN 24422614.

Nugroho, Taufan. (2011). Buku ajar obstetric untuk mahasiswa kebidanan. Yogjakarta: Nuha Medika.

Rukiyah, Ai Yeyeh. (2011). Asuhan kebidanan III nifas. Jakarta: TIM.

Sari, Triana, Mudayati, Sri dan Lasri. (2015). Pengetahuan tentang manajemen laktasi dan sikap ibu post partum dalam proses menyusui, Jurnal Care Vol 3/No 2, 45-54.

$$
\text { Pangan dan Kesehatan }
$$


SDKI. (2013). Survei Demografi dan Kesehatan Indonesia 2012. Badan Kependudukan dan Keluarga Berencana Nasional. Badan Pusat Statistik, Kementerian Kesehatan. Diakses 7 Maret 2020.

Sitepoe, Mangku. (2013). ASI eksklusif arti penting bagi kehidupan. Jakarta: PT Indeks.

Sumastri, Heni. (2012). Hubungan antara frekuensi menyusui dengan inisiasi menstruasi pada ibu yang mempunyai bayi di wilayah kerja Puskesmas Ariodillah Palembang. Diakses 10 September 2020.

Wattimena, Inge, Werdani, Yesiana, Dwi W., Novita, Bernadette Dian and Dewi, D.A.
Liona (2015). Manajemen laktasi dan kesejahteraan ibu menyusui. Jurnal Psikologi UGM, 42 (3), 231-242. ISSN e-ISSN:2460 867X, p-ISSN:0215-8884.

Yovan, Hendrik dan Elise, Putri. (2016). Hubungan pengetahuan tentang manajemen laktasi pada ibu menyusui 0-6 bulan dengan keberhasilan ASI eksklusif di wilayah kerja puskesmas Sungai Kakap. Jurnal Kebidanan, 6 (1), 7480, ISSN-2252-8121.

Yuliarti, Nurheti. (2010). Keajaiban ASI makanan terbaik untuk kesehatan, kecerdasan dan kelincahan si kecil. Yogyakarta: Andi. 